\title{
APPENDIX 1. A MARINE GEOPHYSICAL SURVEY (SITE 211 DSDP) IN THE WHARTON BASIN, INDIAN OCEAN ${ }^{1}$
}

\author{
Bhoopal R. Naini, Lamont-Doherty Geological Observatory of Columbia University, Palisades, New York
}

\begin{abstract}
The Wharton Basin in the vicinity of DSDP Site 211 is characterized by a broad, low-relief northwest-southeast topographic trend along with a local high perpendicular to it. Seismic stratigraphy has indicated two distinct sedimentary layers, an upper acoustically transparent and a lower opaque underlain by the oceanic basement (layer 2). Sediment is found as thin pockets and is devoid on the basement highs. Local free-air gravity anomaly pattern follows the local topography closely. The magnetic anomalies appear to have an approximate east northeast-west southwest trend within the area of study. The forms of benthic life present indicate a soft muddy bottom.
\end{abstract}

\section{INTRODUCTION}

A detailed marine geophysical survey of approximately one square degree region (Figure 1) was carried out by R.V. Robert D. Conrad on Cruise 14, Leg 3 (Singapore to Darwin) during April 1971. This survey was carried out as a possible drill site for DSDP Leg 22. The site was tentatively chosen in a region of earlier reconnaissance work done by R.V. Vema Cruise 24, Leg 10 during August-September of 1967. Subsequently, in January 1972 this site was drilled. The track synopsis of this survey is given in Figure 2.

Site 211 is located in the northern Wharton Basin, northeast Indian Ocean, approximately 130 nautical miles south of the Java Trench. The Wharton Basin is bounded on the west by the Ninetyeast Ridge, on the south by Broken Ridge, and on the east by the Java Trench. This basin is divided into north and south by the Cocos Seamount Chain which trends roughly east-west along latitude $12^{\circ} \mathrm{S}$. The Wharton Basin is the deepest part of the Indian Ocean, the southern part being deeper than the northern part (Heezen and Tharp, 1964). The sediment distribution in this region is thin (Ewing et al., 1969), and the rate of sedimentation has been estimated as being very low (Opdyke and Glass, 1969). The Wharton Basin is comparable in depth to marginal basins in the western Pacific which are characterized by crust of Mesozoic age.

\section{TOPOGRAPHY}

A detailed topographic map of the surveyed region contoured in 100's of meters at variable intervals from corrected soundings (Matthews, 1939) is given in Figure 3. There is a regional approximate northwest-southeast trend in the topography with a gradual increase in depth towards the southwest. The regional rise of topography seaward of the deep-sea trenches has been noted by Watts and Talwani

\footnotetext{
${ }^{1}$ Lamont-Doherty Geological Observatory Contribution No. 2004.
}

(in press) among others. However, the rise seaward of the Java Trench is complicated by local irregularities in topography. A local northeast-southwest trend is observed in the southwest corner of the survey area. This trend represents a topographic high. Besides these, there are other topographic highs possibly due to basement outcropping. The total peak to trough relief in topography for this area is on the order of 900 meters. The free-air gravity anomaly pattern follows closely the local topography (Figure 4).

\section{MAGNETICS}

The regional magnetic pattern of the Wharton Basin is not presently well understood. According to McKenzie and Sclater (1971), this portion of the Wharton Basin is a region where no magnetic lineations have been identified. Furthermore, they have been unable to correlate any of the typical sea-floor spreading anomalies found in some parts of the basin with the time scale of Heirtzler et al. (1968). A residual total intensity magnetic anomaly map of the survey region contoured at 50-gamma intervals is given in Figure 5. The total anomaly range within the area is about 550 gammas. The overall local trend of the magnetic anomalies is different from that of the local gravity and topography. However, in a broad sense, the lineations define a local trend that is approximately east northeast-west southwest. A similar trend has been noted by Falvey (1972) in the northeast Wharton Basin.

\section{SEISMIC REFLECTION AND REFRACTION}

Figures $6 \mathrm{a}$ to $6 \mathrm{e}$ represent low-frequency airgun seismic profiles, indicating sediment cover varying between 0 and $0.7 \mathrm{~s}$ two-way vertical reflection time. Basement (layer 2) is traceable underlying the sediment throughout the region.

The sediment consists of two distinct layers. The topmost is a thin (up to 100 meters) layer of pelagic sediment which is acoustically transparent. Underlying this is an acoustically opaque stratified layer. This opaque layer is of variable thickness. Underlying the sediment is oceanic basement (layer 2). The basement topography is rough with 


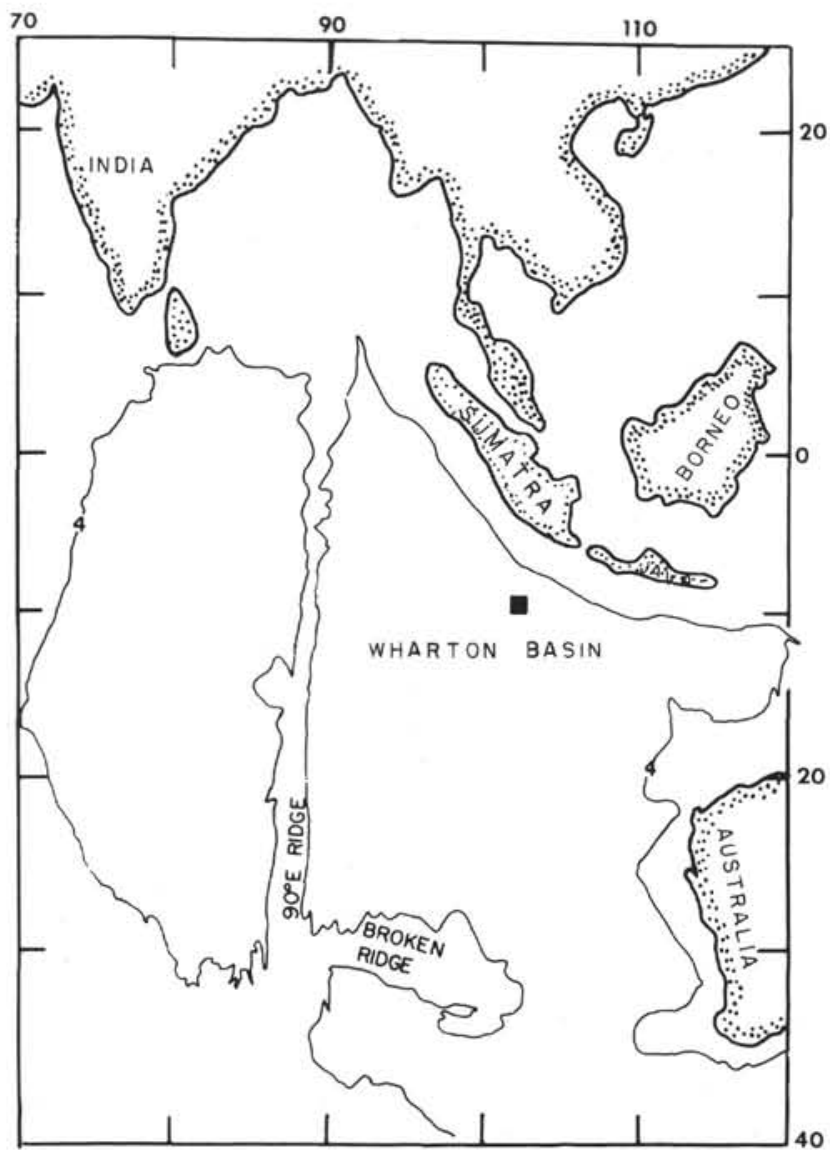

Figure 1. General location of the survey area (black square) in eastern Indian Ocean; major topographic features outlined by $4-\mathrm{km}$ isobath.

isolated highs, faults, and step-like features (Figure $6 \mathrm{a}$ to $6 e)$.

A sediment isopach map of this region has been contoured using thickness of sediment determined at 10-min intervals along the ship's track. The thicknesses have been contoured in tenths of seconds of two-way vertical reflection time $(\sim 100$ meters thick assuming a velocity of $2.0 \mathrm{~km} / \mathrm{s}$ ). The sedimentary distribution as seen in Figure 7 represents a parallel to subparallel trend to the northeastsouthwest local topographical trend. The sediment is thick along basement depressions and forms small lens-shaped basins. The thickest sediment is found in the northwestern area where the total thickness reaches up to $0.7 \mathrm{~s}$. This sedimentary lens has a northeast-southwest trend and is flanked on the southern side by a ridge and on the northern side by isolated basement high topography.

A sonobuoy was recorded at $9^{\circ} 35^{\prime} \mathrm{S}$ and $102^{\circ} 17^{\prime} \mathrm{E}$ (Figure 2). Wide-angle reflections have yielded two sedimentary layers with $2.41 \mathrm{~km} / \mathrm{s}$ and $2.91 \mathrm{~km} / \mathrm{s}$ interval velocity, having a thickness of $0.18 \mathrm{~km}$ and $0.59 \mathrm{~km}$, respectively. The former velocity is associated with the acoustically transparent layer and the latter with the opaque layer described earlier. Refraction arrivals from the basement yielded an apparent velocity of $4.76 \mathrm{~km} / \mathrm{s}$. This is in general agreement with the velocity for layer 2 , which is

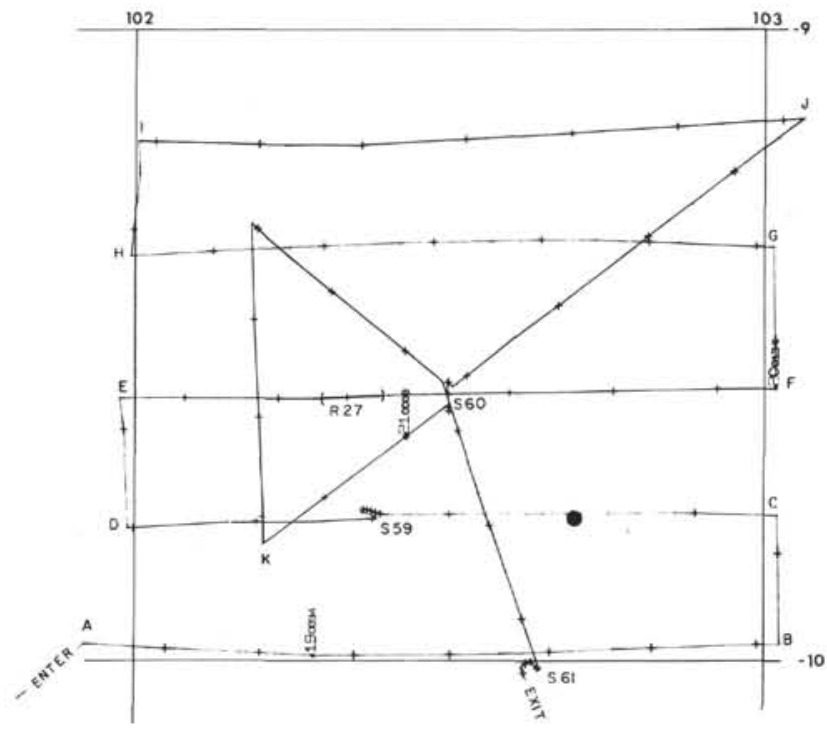

Figure 2. Details of the track for the survey. Plus marks represent time in hours spaced at 1-hour intervals, and the satellite fixes are marked with time and day. Numbers with prefix $S$ correspond to stations and $R$ to sonobuoy, duration of sonobuoy is shown in parenthesis. $A B, C D$, etc. represent locations of seismic reflection profiles of Figures $6 a$ to 6 . Black circle (also in Figures 3, 4, 5, and 7) is the location of DSDP Site 211.

$5.19 \pm 0.64 \mathrm{~km} / \mathrm{s}$ for the Indian Ocean (Shor and Raitt, 1969).

\section{BOTTOM PHOTOGRAPHY AND CORES}

At the three stations, S59, S60, and S61 (see Figure 2 for locations), bottom photographs were taken. All the photographs reveal a bottom that is scattered with holothurian faecal knots, some intact and some disturbed (Figure 8a to 8e). Also found are mounds with a central hole and radiating grooves, worm tracks, and holothurians. The presence of holothurians indicates a soft muddy bottom.

Three piston cores were also collected at these stations. All the cores consisted of clays with radiolarians and diatoms with intermittent volcanic ash and sand layers. A study of diatoms in the three cores has yielded an age of middle to late Pleistocene at stations 59 and 60 and early Pleistocene at station 61 (L. Burckle, personal communication).

\section{CONCLUSIONS}

This work has revealed that:

1) The area of study has a broad, low topographic relief with an approximate northwest-southwest trend with another local trend that is perpendicular to this which represents a topographic high.

2) The seismic stratigraphy represents two sedimentary layers, consisting of a top acoustically transparent layer up to about 100 meters thick and a lower opaque layer that is stratified and variable in thickness. The sedimentary layers 


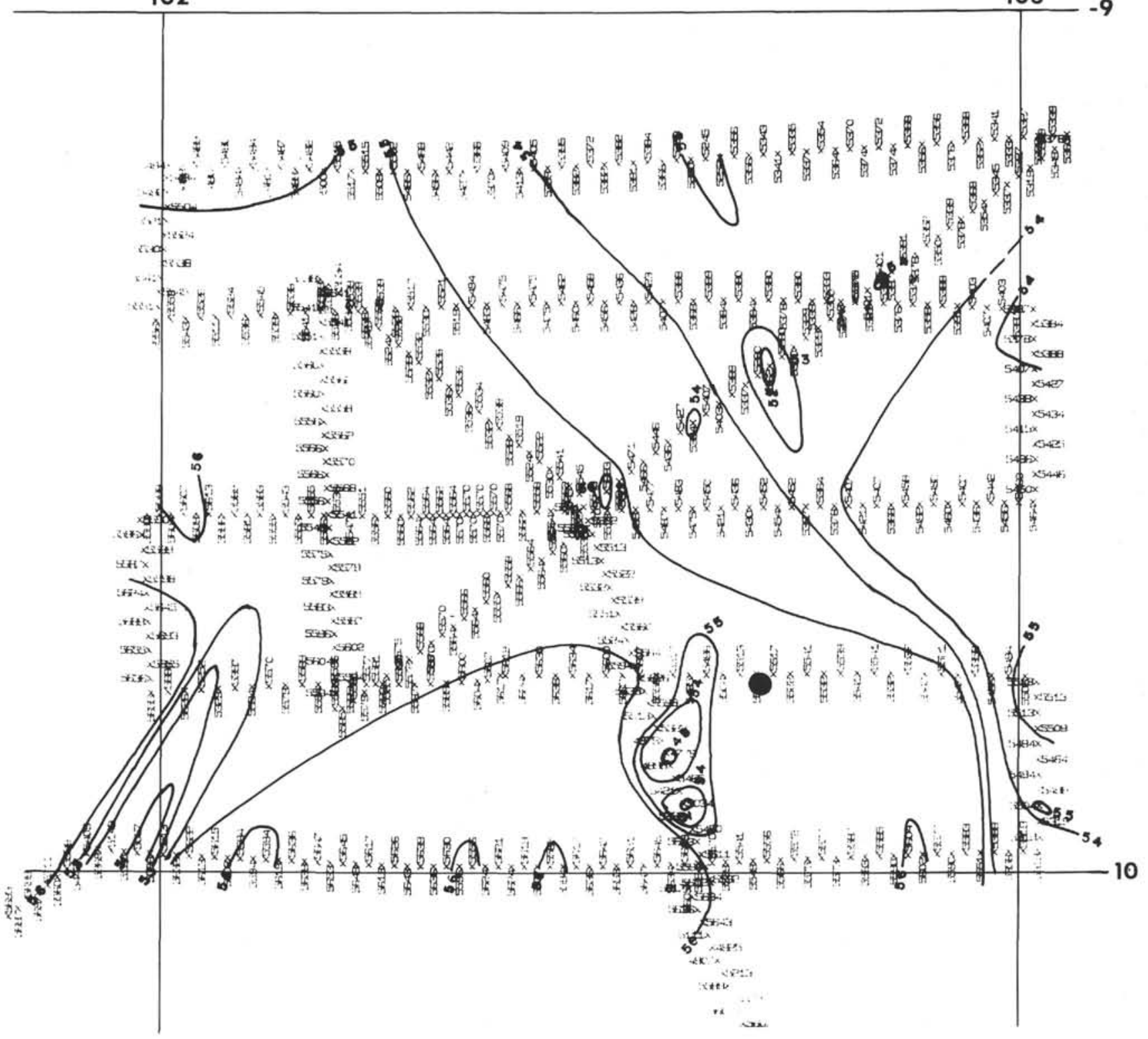

Figure 3. Soundings in corrected meters plotted along the ship's track in the survey area; contours are in 100 's of meters at variable intervals.

are underlain by oceanic basement (layer 2). The basement is rough, faulted, and has an apparent velocity of 4.76 $\mathrm{km} / \mathrm{s}$.

3) The free-air gravity anomaly pattern follows closely the local topography.

4) The magnetic lineations have an approximate east northeast-west southwest local trend.

5) The diatoms found in the piston cores represent an oldest age of early Pleistocene.

6) The bottom is soft and muddy as evidenced by the abundance of benthic fauna.

\section{ACKNOWLEDGMENTS}

I thank Mr. George Carpenter, Dr. Stephen L. Eittreim, Mr. Olav Eldholm, and Dr. Anthony B. Watts for criticism of the paper. I am grateful to Mr. John I. Ewing for his guidance throughout this work. Many thanks are due Dr. Roger L. Larson for helpful discussions, officers and crew of the R/V Conrad, and in particular, Mr. George Carpenter who served as chief scientist and Miss Betty Batchelder for drafting and typing help. This work was supported by Grant GA 28338 from the National Science Foundation and Contract N00014-67-A-0108-0004 from the U. S. Navy Office of Naval Research.

\section{REFERENCES}

Ewing, M., Eittreim, S., Truchan, M., and Ewing, J. I., 1969. Sediment distribution in the Indian Ocean: Deep-Sea Res., v. 16, p. 231-248.

Falvey, D. A., 1972. On the origin of marginal plateaus and adjacent ocean basins off Northern Australia: Ph.D. thesis, School of Applied Geology, University of New South Wales. 


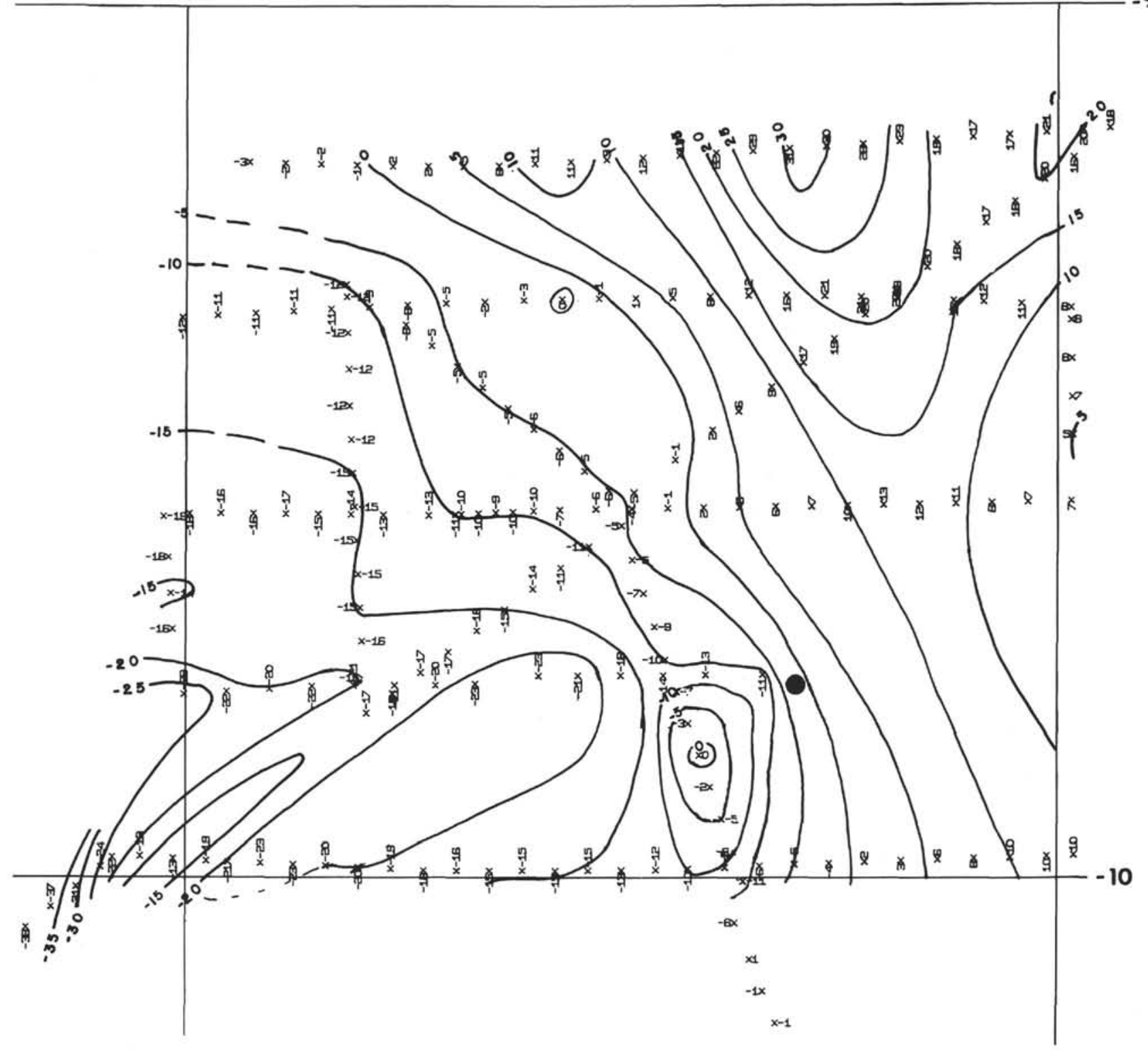

Figure 4. Gravity map of the survey area: free-air anomaly values plotted along the ship's track and contoured at 5-milligal intervals.

Heezen, B. C. and Tharp, M., 1964. Tectonic fabric of the Atlantic and Indian Oceans, and continental drift: Phil. Trans. Roy. Soc., London, Ser. A, v. 259, p. 150-171.

Heirtzler, J. R., Dickson, G. O., Herron, E. M., Pitman, W. C., III, and Le Pichon, X., 1968. Marine magnetic anomalies, geomagnetic field reversals, and motions of the ocean floor and continents: J. Geophys. Res., v. 73, p. 2119-2136.

Matthews, D. J., 1939. Tables of the velocity of sound in pure water and sea water for use in echo sounding and sound ranging: London (Admiralty Office).

McKenzie, D. and Sclater, J. G., 1971. The evolution of Indian Ocean since the Late Cretaceous: Geophys. J.
Roy. Astr. Soc., v. 25, p. 437-528.

Opdyke, N. D. and Glass, B. P., 1969. The paleomagnetism of sediment cores from the Indian Ocean: Deep-Sea Res., v. 16, p. 249-261.

Shor, G. G., Jr. and Raitt, R. W., 1969. Explosion seismic refraction studies of the crust and upper mantle in the Pacific and Indian oceans: In The Earth's Crust and Upper Mantle: Geophys. Mono. 13, P. J. Hart (Ed.), Washington (Am. Geophys. Un.), p. 225-230.

Watts, A. B. and Talwani, M., in press. Gravity anomalies seaward of deep-sea trenches and their tectonic implications. Geophys. J. Roy. Astr. Soc. 


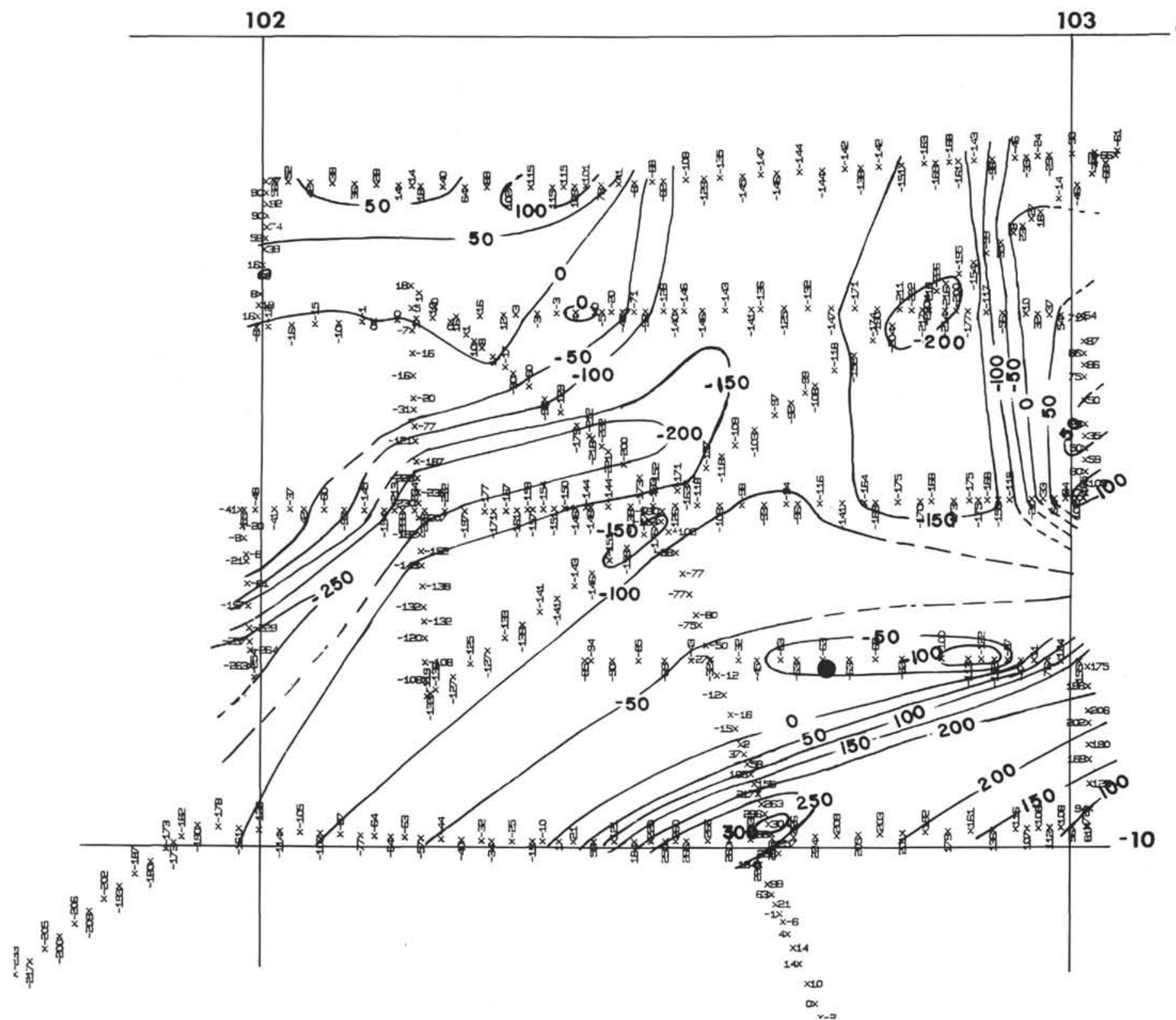

Figure 5. Residual total intensity magnetic field values plotted along the ship's track, contoured at 50-gamma intervals in the survey area. 

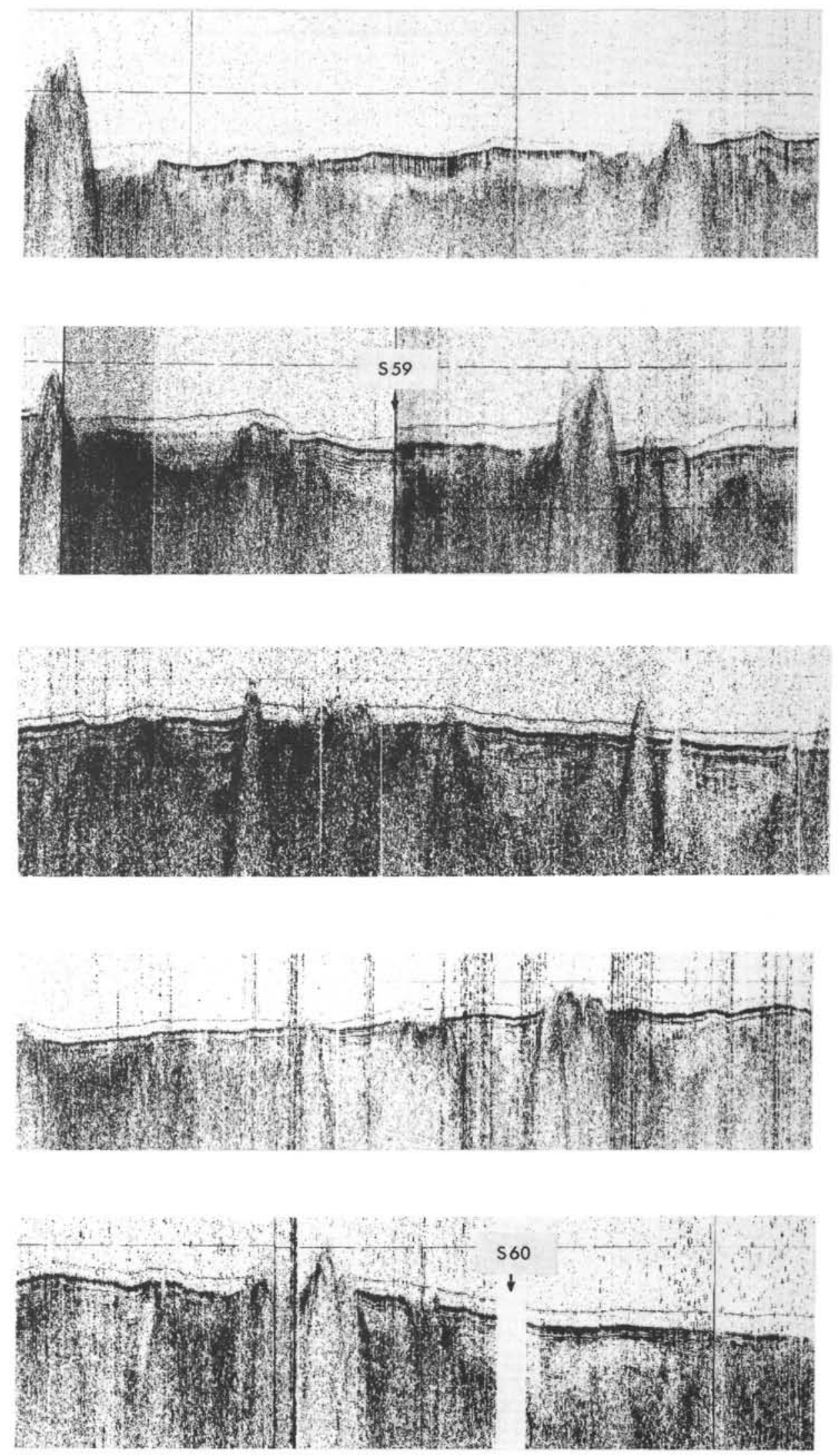

Figure 6. Seismic reflection profiles along sections (a) $A B C$, (b) $C D E$, (c) $F G H$, (d) $H I F$, and (e) JK (Figure 2) showing numerous features described in text. Vertical scale is two-way reflection time in seconds, arrows on top identify stations. 


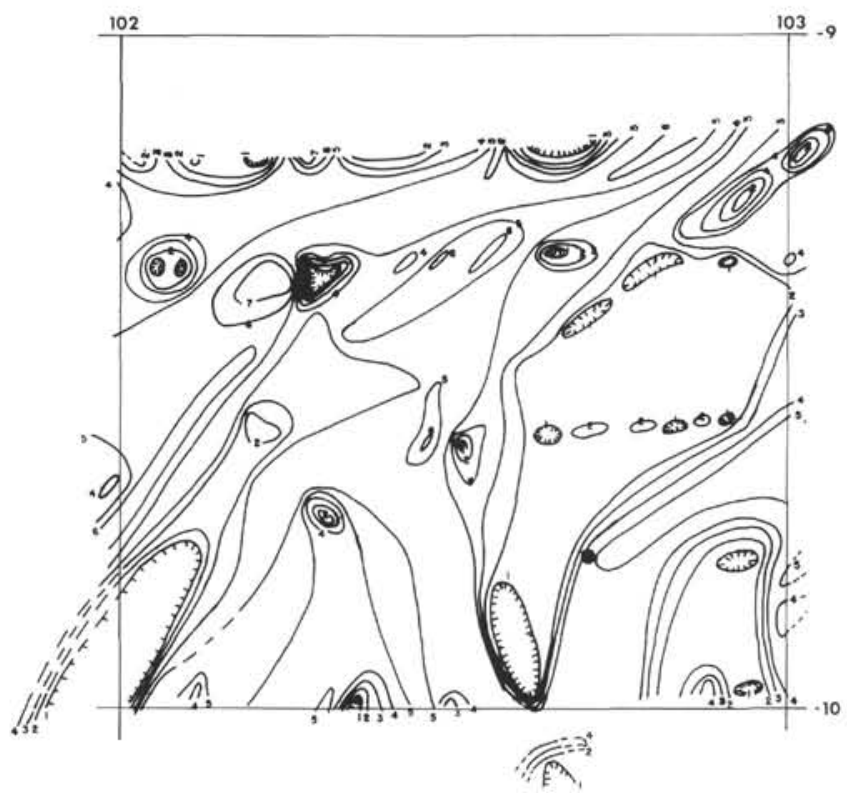

Figure 7. Sediment isopach map of the survey area based on readings of travel time through sediment at 10-min intervals along the ship's track, contoured in tenths of seconds two-way vertical reflection time. Hachures are towards basement outcrop. 

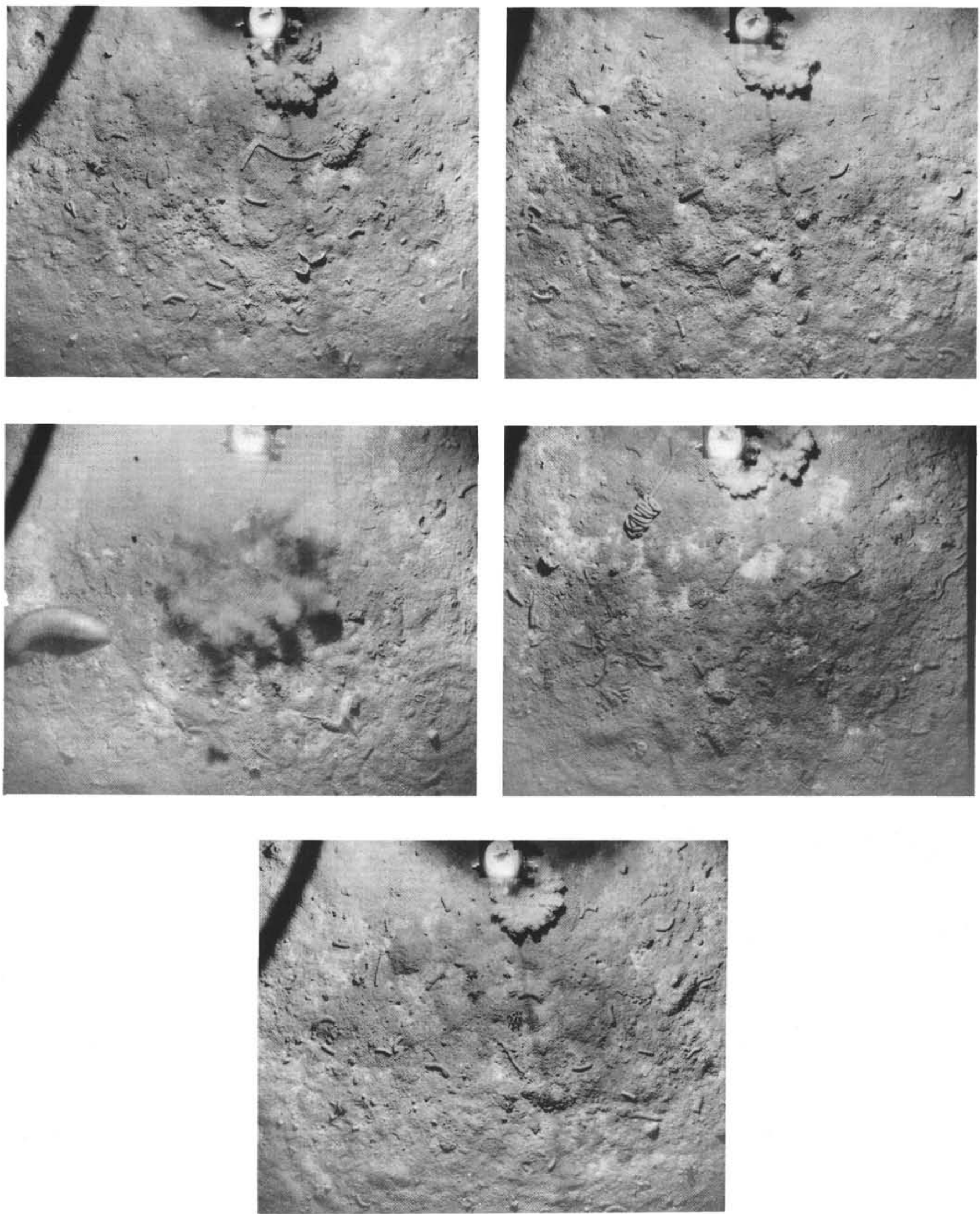

Figure 8. Bottom photographs, at station 59 (Figure 2) showing (a) an intace holothurian faecal knot, (b) disturbed holothurian faecal knots and a mound with a central hole and radiating grooves, (c) at station 61 (Figure 2) sea cucumber, (d) faecal knots intace, (e) disturbed. Area covered in each photograph is about 2 by 1 meters. 